Article

\title{
Cryptosporidium sciurinum n. sp. (Apicomplexa: Cryptosporidiidae) in Eurasian Red Squirrels (Sciurus vulgaris)
}

\author{
Jitka Prediger ${ }^{1,+}{ }^{\text {, Jana Ježková }}{ }^{1,+}$, Nikola Holubová ${ }^{1,2}{ }^{2}$ Bohumil Sak ${ }^{2}$, Roman Konečný ${ }^{1}$, Michael Rost $^{1}$, \\ John McEvoy ${ }^{3}$, Dušan Rajský ${ }^{4}$ and Martin Kváč 1,2,* \\ 1 Faculty of Agriculture, University of South Bohemia in České Budějovice, Studentská 1668, \\ 37005 České Budějovice, Czech Republic; jitka.prediger@gmail.com (J.P.); jezkja@seznam.cz (J.J.); \\ nikoleto@seznam.cz (N.H.); konecnyroman@centrum.cz (R.K.); rost@jcu.cz (M.R.) \\ 2 Institute of Parasitology, Biology Centre of the Czech Academy of Sciences, Branišovská 31, \\ 37005 České Budějovice, Czech Republic; casio@paru.cas.cz \\ 3 Microbiological Sciences Department, North Dakota State University, 1523 Centennial Blvd, Van Es Hall, \\ Fargo, ND 58102, USA; john.mcevoy@ndsu.edu \\ 4 Faculty of Forestry, Technical University in Zvolen, T.G. Masaryka 24, 96001 Zvolen, Slovakia; \\ dusan.rajsky@gmail.com \\ * Correspondence: kvac@paru.cas.cz; Tel.: +420-387775419 \\ + These authors contributed equally.
}

\section{check for} updates

Citation: Prediger, J.; Ježková, J.; Holubová, N.; Sak, B.; Konečný, R.; Rost, M.; McEvoy, J.; Rajský, D.; Kváč, M. Cryptosporidium sciurinum $\mathrm{n}$. sp. (Apicomplexa: Cryptosporidiidae) in Eurasian Red Squirrels (Sciurus vulgaris). Microorganisms 2021, 9, 2050. https://doi.org/10.3390/ microorganisms 9102050

Academic Editors: Chao-Nan Lin and Peck Toung Ooi

Received: 20 August 2021

Accepted: 24 September 2021

Published: 28 September 2021

Publisher's Note: MDPI stays neutral with regard to jurisdictional claims in published maps and institutional affiliations.

Copyright: (c) 2021 by the authors. Licensee MDPI, Basel, Switzerland. This article is an open access article distributed under the terms and conditions of the Creative Commons Attribution (CC BY) license (https:/ / creativecommons.org/licenses/by/ $4.0 /)$.

\begin{abstract}
Cryptosporidium spp. are common protozoan pathogens in mammals. The diversity and biology of Cryptosporidium in tree squirrels are not well studied. A total of 258 Eurasian red squirrels (Sciurus vulgaris) from 25 and 15 locations in the Czech Republic and Slovakia, respectively, were examined for Cryptosporidium spp. oocysts and specific DNA at the SSU, actin, HSP70, TRAP-C1, COWP, and gp60 loci. Out of 26 positive animals, only juveniles $(9 / 12)$ were microscopically positive (18,000 to 72,000 OPG), and molecular analyses revealed the presence of Cryptosporidium sp. ferret genotype in all specimens. Oocysts obtained from naturally-infected squirrels measured 5.54-5.22 $\mu \mathrm{m}$ and were not infectious for laboratory mice (BALB/c and SCID), Mongolian gerbils, Guinea pigs, Southern multimammate mice, chickens, or budgerigars. None of naturally infected squirrels showed clinical signs of disease. The frequency of occurrence of the ferret genotype in squirrels did not vary statistically based on host age, gender or country of capture. Phylogenetic analysis of sequences from six loci revealed that Cryptosporidium sp. ferret genotype is genetically distinct from the currently accepted Cryptosporidium species. Morphological and biological data from this and previous studies support the establishment of Cryptosporidium sp. ferret genotype as a new species, Cryptosporidium sciurinum n. sp.
\end{abstract}

Keywords: occurrence; biology; course of infection; infectivity; oocyst size; phylogeny; Cryptosporidium sp. ferret genotype

\section{Introduction}

Cryptosporidium is a genus of single-cell protist parasites that infect the gastrointestinal, respiratory, and/or the urogenital tract of most vertebrates, including humans, causing the disease cryptosporidiosis [1]. The course of infection and severity of the disease depends on a host factors such as age, competence and maturity of the immune system, condition, the presence of secondary infections, and on the characteristics of the Cryptosporidium species or genotype [2]. Most of the species validly described so far (48) are narrowly host specific, and only a small number, including C. parvum, C. ubiquitum, and C. baileyi, have a broad host range [3,4]. In addition to the validly described species, dozens of genotypes have been described that lack sufficient data to justify a species designation. Genotypes are typically named for the host from which the novel Cryptosporidium DNA sequence is first identified. For example, C. suis was originally described as the Cryptosporidium pig genotype because it was first identified in a pig [5]. New genotypes are most frequently 
described from partial sequences of the small subunit rRNA gene. The squirrel, family Sciuridae, is one of the most diverse and widely distributed families of mammals, and they host several species and genotypes of Cryptosporidium, some of which are infectious to humans and can cause severe and life-threatening diarrhoea [6].

Tree squirrels diverged from ground squirrels about 30 million years ago, and this polyphyletic tribe comprises hundreds of extant species. Cryptosporidium was first reported in a tree squirrel in 1982, when Sundberg et al. [7] isolated oocysts from an eastern grey squirrel (Sciurus carolinensis). Current [8] subsequently reported Cryptosporidium oocysts in a fox squirrel (Sciurus niger). Both authors identified the isolates as C. parvum, but this was likely incorrect, based on our present knowledge. We now know that several distinct Cryptosporidium species and genotypes with overlapping oocyst sizes infect tree squirrels. Four species and five genotypes of Cryptosporidium have been described in tree squirrels inhabiting North America: C. ubiquitum, Cryptosporidium sp. chipmunk genotype I, deer mouse genotype III, and skunk genotype in the American red squirrel (Tamiasciurus hudsonicus); C. baileyi, C. muris, C. ubiquitum, Cryptosporidium sp. chipmunk genotype I, deer mouse genotype III, and skunk genotype in the Eastern grey squirrel (Sciurus carolinensis); C. ubiquitum in the Fox squirrel (Sciurus niger) [7,9-12]. Fewer studies have reported on Cryptosporidium in tree squirrels outside of North America. In China, C. paroum, C. wrairi, and Cryptosporidium sp. rat genotype II have been detected in wild Pallas's squirrels (Callosciurus erythraeus), and C. paroum, C. ratti, Cryptosporidium sp. rat genotype II, ferret genotype, and chipmunk genotype III have been reported in Eurasian red squirrels [13-15]. In Europe, native Eurasian red squirrels are almost exclusively infected with Cryptosporidium sp. ferret genotype [16,17], although other Cryptosporidium species and genotypes, such as C. ubiquitum, Cryptosporidium sp. skunk genotype, and chipmunk genotype I, have been reported in areas where the Eurasian red squirrel is threatened by invasive, non-native species from Asia and North America [16,17]. It can be concluded from the literature that Eurasian red squirrels primarily host Cryptosporidium sp. ferret genotype, whereas the C. ubiquitum and Cryptosporidium skunk genotypes are most common in North American squirrels [7,9-17].

This study aimed to describe the biological, morphological, and genetic characteristics of Cryptosporidium sp. ferret genotype from Eurasian red squirrels in Central Europe. Our data show that the ferret genotype is the major Cryptosporidium species infecting Eurasian red squirrels in this region, and it is genetically and biologically distinct from valid Cryptosporidium species. We therefore propose that it be named Cryptosporidium sciurinum n. sp.

\section{Materials and Methods}

\subsection{Ethics Statement}

Traps were checked at least twice per day and handling time was minimized to reduce animal stress; all applicable international, national, and institutional guidelines for the care and use of animals were followed. Permits for trapping and handling squirrels and for the transmission study complied with the laws of the Czech Republic (Act No. 246/1992 Coll., on the protection of animals against cruelty). The study design was approved by the ethical committees at the Biology Centre of CAS, the State Veterinary Administration, and the Central Commission for Animal Welfare under protocol Nos. MZP/2019/603/1411 and $35 / 2018$.

\subsection{Trapping and Specimen Collection}

Faecal samples were collected between June 2019 and June 2021 from Eurasian red squirrels at 25 locations, including seven rescue stations in the Czech Republic and 15 locations in Slovakia (Figure 1). A total of 265 faecal samples were obtained from 258 Eurasian red squirrels. Of these, 147 samples were from squirrels trapped in the wild and 111 were from animals housed at rescue stations. Two squirrels kept at a rescue station (nos. 45901 and 51489) were screened repeatedly. Wild squirrels were live-captured in a 
Sherman box baited with a mixture of nuts and seeds. Each trapped squirrel was placed into a wire-mesh handling cone to minimize stress during handling and the sex, age, and body condition were recorded following [18]. The presence of any faecal material on the fur around the rectum was also recorded. After release of the trapped animal, faecal samples were collected from traps and individually placed in a sterile plastic tube, which was stored at $4-8{ }^{\circ} \mathrm{C}$ until subsequent processing. The consistency of faecal samples was recorded at the time of collection. A faecal smear was prepared from each sample, stained with anilinecarbol-methyl violet (ACMV) [19], and examined for the presence of Cryptosporidium spp. oocysts. Oocysts were quantified and the infection intensity was estimated using the method described by Kváč et al. [20]. Briefly, the slide was weighed to the nearest $0.001 \mathrm{~g}$ before and after preparation of the smear to determine the mass of faecal material added to the slide. After ACMV staining, all oocysts on the slide were counted and the number of oocysts per gram of faeces was calculated. Oocysts were enumerated from triplicate smears prepared from each sample. All samples were subsequently screened in triplicate for the presence of Cryptosporidium-specific DNA by PCR/sequencing of a fragment of the small subunit rRNA gene (SSU). If Cryptosporidium-specific DNA was detected, genotyping at other loci was performed as described below.

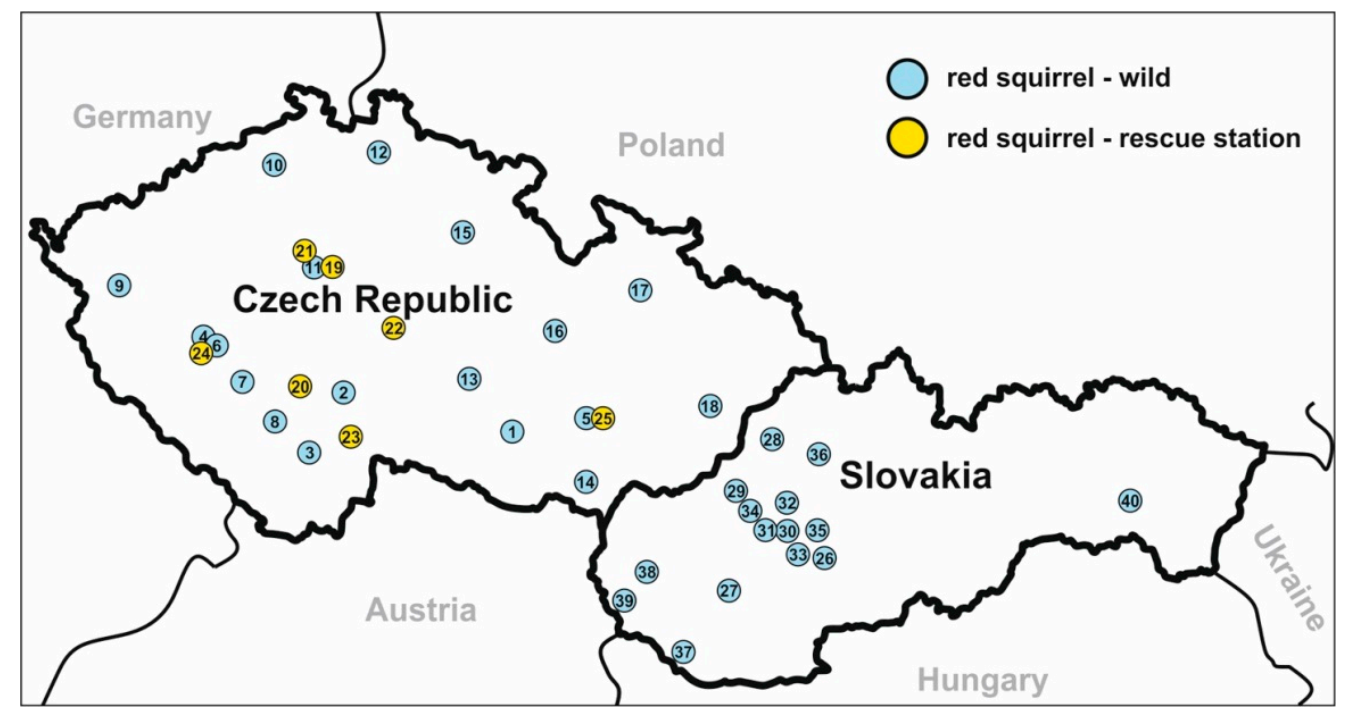

Figure 1. Sampling localities in the Czech Republic and Slovakia: For each site, the number indicates the name of locations (1) Třebíč; (2) Brandlín; (3) České Budějovice; (4) Plzeň; (5) Brno; (6) Starý Plzenec; (7) Chocenice; (8) Strakonice; (9) Mariánské Lázně; (10) Ústí nad Labem; (11) Praha; (12) Liberec; (13) Jihlava; (14) Břeclav; (15) Jaroměř; (16) Svitavy; (17) Bruntál; (18) Valašské Meziříčí; (19) Jinonice; (20) Makov; (21) Praha; (22) Vlašim; (23) Třeboň; (24) Plzeň; (25) Brno; (26) Zvolen; (27) Nitra; (28) Považská Bystrica; (29) Trenčín; (30) Handlová; (31) Prievidza; (32) Turčianské Teplice; (33) Žiar nad Hronom; (34) Bánovce nad Bebravou; (35) Kremnica; (36) Martin; (37) Gabčíkovo; (38) Pezinok; (39) Bratislava; (40) Košice.

\subsection{Source of Oocysts of Cryptosporidium sp. Ferret Genotype}

An isolate of Cryptosporidium sp. ferret genotype was obtained from a juvenile Eurasian red squirrel at a rescue station (isolate 45901, locality no. 23). Faecal samples from this squirrel were individually collected into sterile $50 \mathrm{~mL}$ vials with a few drops of $\mathrm{dH}_{2} \mathrm{O}$ and stored at $4-8{ }^{\circ} \mathrm{C}$. Oocysts were purified using caesium chloride gradient centrifugation [21] and used for morphometry and transmission studies (described below). Oocyst viability was examined following propidium iodide (PI) staining by a modified assay of Sauch et al. [22]. The oocysts were stored in PBS at $4-8{ }^{\circ} \mathrm{C}$ for a maximum of 4 weeks. 


\subsection{Molecular Characterization}

Total genomic DNA (gDNA) was extracted from 5000 purified oocysts, $200 \mathrm{mg}$ of faeces or $200 \mathrm{mg}$ of tissue (see Clinical and Pathomorphological Examinations) by bead disruption (all sample types) for $60 \mathrm{~s}$ at $5.5 \mathrm{~m} / \mathrm{s}$ using $0.5 \mathrm{~mm}$ glass beads in a FastPrep ${ }^{\circledR} 24$ Instrument (MP Biomedicals, CA, USA) followed by isolation/purification using Exgene ${ }^{\mathrm{TM}}$ Stool DNA mini (GeneAll Biotechnology Co. Ltd., Seoul, Korea) or DNeasy Blood \& Tissue Kit (Qiagen, Hilden, Germany) in accordance with the manufacturer's instructions. Purified DNA was stored at $-20{ }^{\circ} \mathrm{C}$ prior to amplification by PCR. Nested-PCR protocols were used to amplify partial sequences of genes encoding $S S U$, actin, the $70 \mathrm{kDa}$ heat shock protein (HSP70), the thrombospondin-related adhesive protein of Cryptosporidium-1 (TRAPC1), Cryptosporidium oocyst wall protein (COWP), and the $60 \mathrm{kDa}$ glycoprotein (gp60) using previously published protocols and primers [23-29]. Negative (molecular grade water) and positive controls (DNA of C. tyzzeri subtype family XIa) were included in each PCR amplification.

\subsection{Sequence and Phylogenetic Analysis}

Secondary PCR products were purified using Gen Elute Gel Extraction Kit (Sigma, St. Louis, MO, USA) and sequenced in both directions using an ABI Prism ${ }^{\mathrm{TM}}$ Dye Terminator Cycle Sequencing kit (Applied Biosystems, Foster City, CA, USA) using secondary PCR primers according to the manufacturer's instructions in a commercial laboratory (SEQme, Dobřišs, Czech Republic). Sanger sequencing chromatogram files were edited using the ChromasPro 2.1.8 software (Technelysium, Pty, Ltd., South Brisbane, Australia), the obtained nucleotide sequences of each gene were aligned with each other and with reference sequences from GenBank (https:/ / www.ncbi.nlm.nih.gov, accessed on 9 August 2021) using MAFFT version 7 online server (http:/ / mafft.cbrc.jp/alignment/software/, accessed on 9 August 2021) and manually edited and trimmed using BioEdit v.7.0.5 [30]. Maximum likelihood (ML) and Neighbor-joining (NJ) trees were constructed using the Molecular Evolutionary Genetics Analysis (MEGAX) software after computing the most appropriate evolutionary models and values of all parameters for each model. Bootstrap support for branching was based on 1000 replications. Estimates of pairwise distances between species as the number of base substitutions per site from between sequences were calculated in MEGAX. Sequences have been deposited in GenBank under the accession numbers MZ726453-MZ726454 (SSU), MZ772035-MZ772036 (actin), MZ772046-MZ772047 (HSP70), MZ772037-MZ772038 (TRAP-C1), MZ772044-MZ772045 (COWP), and MZ772039MZ772042 (gp60).

\subsection{Oocyst Morphometry}

The length and width of Cryptosporidium sp. ferret genotype oocysts $(n=50)$ was determined using a digital analysis of images (Olympus cellSens Entry 2.1 software, Olympus Corporation, Shinjuku, Tokyo, Japan) collected using an Olympus Digital Colour Camera DP73 (Olympus), using differential interference contrast (DIC) microscopy at $1000 \times$ magnification (Olympus IX70, Tokyo, Japan). These measurements were used to calculate the mean length, width, and the length-to-width ratio. Oocyst size was measured using the same microscope and by the same person. Faecal smears with oocysts of Cryptosporidium sp. ferret genotype were stained by modified ACMV, Ziehl-Neelsen (ZN; [31]) and labelled with a Cy3-labelled mouse monoclonal antibody targeting the Cryptosporidium oocyst outer wall antigenic sites (A400Cy2R-20X, Crypt-a-Glo, Waterborne, Inc., New Orleans, LA, USA) and with genus-specific, FITC-conjugated antibodies (IFA; Cryptosporidium IF Test, Crypto cel, Cellabs Pty Ltd., Brookvale, Australia). Type microphotographs of oocysts were taken from each staining/labelling.

\subsection{Transmission Studies}

All animals used in transmission studies were screened every day for the presence of oocysts of Cryptosporidium spp. and specific DNA ( $S S U$ ) a week prior to transmission 
studies. Five seven-day-and-eight-week-old SCID (strain C.B-17) and BALB/c mice (Mus musculus), five seven-day-and-eight-week-old Mongolian gerbils (Meriones unguiculatus), five seven-day-and-eight-week-old guinea pigs (Cavia porcellus), five seven-day-and-eightweek-old Southern multimammate mice (Mastomys coucha), five seven-day-old chickens (Gallus gallusf. domestica), and five adult budgerigars (Melopsittacus undulatus) were used for transmission studies. Three animals from each strain/species were used as a negative control. To prevent environmental contamination with Cryptosporidium spp., animals were housed in plastic cages/aviaries and supplied with a sterilized diet for appropriate hostspecies and sterilized water ad libitum. Seven-day-and-eight-week-old animals were each inoculated orally by stomach tube with 5000 purified viable oocysts suspended in $50 \mu \mathrm{L}$ and $200 \mu \mathrm{L}$ of distilled water, respectively. Faecal samples from all inoculated and control animals were collected daily for 20 days. All samples were screened for the presence of Cryptosporidium oocysts and specific DNA using microscopy (following ACMV staining) and PCR amplification of the SSU gene, respectively (methods described above). Animals were housed under conditions in accordance with Czech legislation (Act No 246/1992 Coll., on protection of animals against cruelty). Animal caretakers always wore sterile shoe covers, disposable coveralls, and disposable gloves when they entered the experimental room. Woodchip bedding and disposable protective clothing were removed from the experimental room and incinerated.

\subsection{Clinical and Pathomorphological Examinations}

All animals were sacrificed in accordance with Czech legislation (Act No 246/1992 Coll) at 20 days post-infection (DPI), and the complete examination of all gastrointestinal organs was conducted at necropsy. Tissue specimens from the oesophagus; stomach; duodenum; proximal, central and distal jejunum; ileum; caecum; colon; liver; spleen; kidney; bladder and lung were collected using different sterile dissection tools for each location and processed for histology [32], scanning electron microscopy (SEM) [33], and PCR amplification of the SSU gene. Histology sections $(5 \mu \mathrm{m})$ were stained with hematoxylin and eosin (HE) and periodic acid-Schiff (PAS) and were examined at 100-400× magnification (Olympus IX70). Specimens for SEM were examined using a JEOL JSM-7401F-FE scanning electron microscope (Jeol, Tokyo, Japan).

\subsection{Statistical Analysis}

For the evaluation of difference in relative frequency in positivity between groups (country, age, gender), we used the two sample test for equality of proportions without continuity correction. Differences in oocyst sizes were tested using Hotelling's multivariate version of the 2 sample $t$-test, package ICSNP: Tools for Multivariate Nonparametrics (Nordhausen et al. 2018) in R 4.1.0. [34]. The hypothesis tested was that two-dimensional mean vectors of measurement are the same in the two populations being compared.

\section{Results}

Cryptosporidium-specific DNA was identified in 26 squirrels by nested PCR targeting the SSU gene (Table 1 ). Of these 26 squirrels, nine (34.6\%) were microscopically positive for the presence of Cryptosporidium oocysts, with an infection intensity ranging from 18,000 to 72,000 OPG. Microscopically detectable infection was observed exclusively in juvenile squirrels. However, the occurrence of infection detected by PCR did not differ between juveniles $(8.9 \%)$ and adults $\left(11.8 \% ; \chi^{2}=0.52991, d . f .=1, p\right.$-value $\left.=0.4666\right)$. Similarly, the occurrence of infection was not affected by host gender $\left(\chi^{2}=0.2966, d . f .=1, p\right.$-value $\left.=0.5860\right)$ or country of capture $\left(\chi^{2}=0.0028, d . f .=1, p\right.$-value $=0.9388$; Table S1). Phylogenetic trees (ML, NJ) constructed from SSU sequences showed the presence of Cryptosporidium sp. ferret genotype in all samples (Figure 2). Out of the 26 Cryptosporidium-positive squirrels, $26,26,19,16,15$, and 26 were genotyped by sequence analysis of the $S S U$, actin, HSP70, $T R A P-C 1, C O W P$, and gp60 genes, respectively. For the remaining samples, either the PCR product was not amplified or the sequencing failed. For the actin, HSP70, TRAP-C1, 
and COWP genes, isolates of Cryptosporidium sp. ferret genotype in this study shared $100 \%$ identity with each other and $99.8-100 \%$ identity with previously reported sequences (Figures S1-S4). Sequences of the gp60 gene were obtained from all 26 isolates and were identified as Cryptosporidium sp. ferret genotype subtype families VIIIb $(n=12)$ and VIIIc $(n=14$; Figure 3).

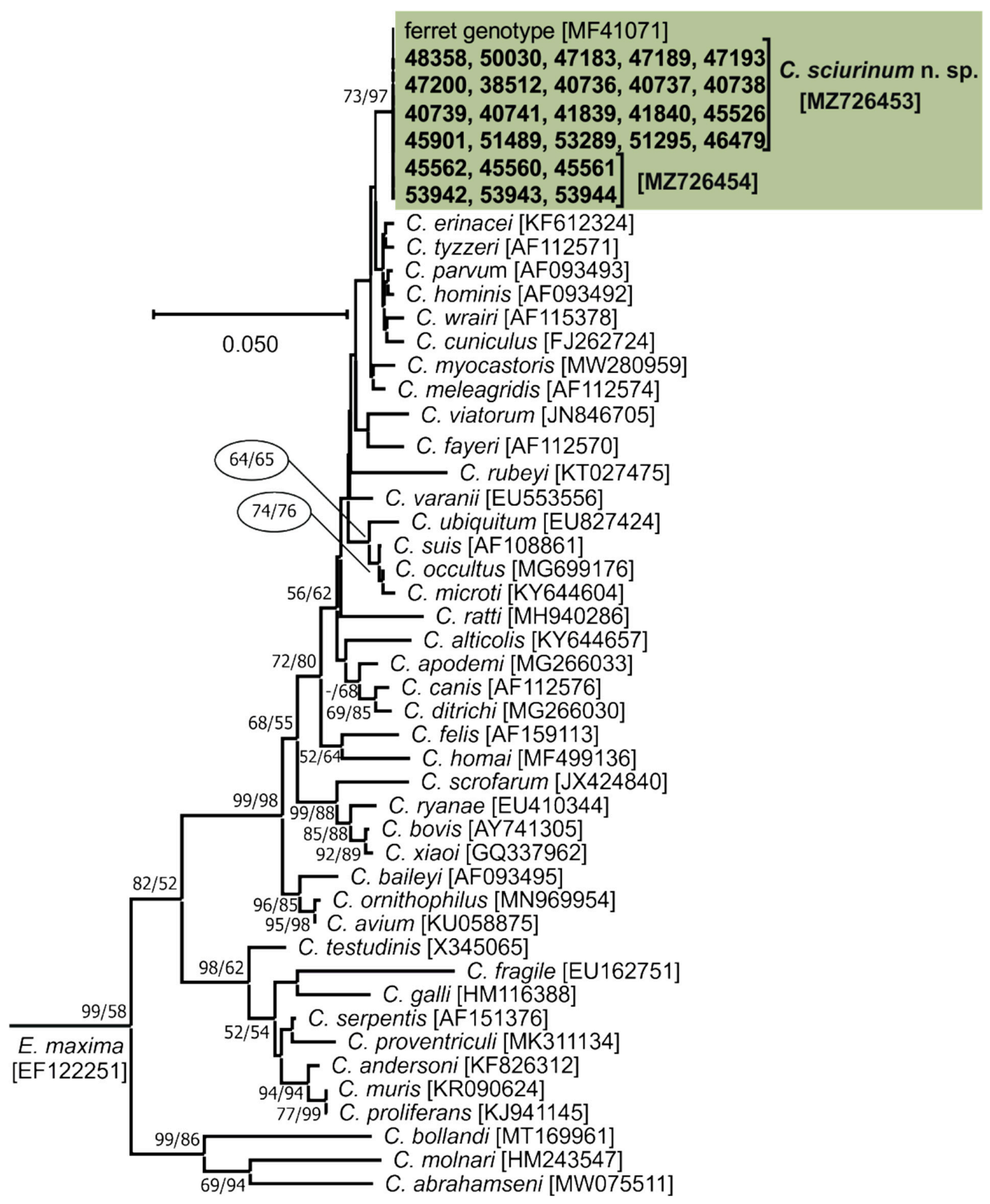

Figure 2. Evolutionary relationships of Cryptosporidium spp. at the small subunit rRNA (SSU) locus inferred by Maximum Likelihood (ML) and Neighbor-Joining (NJ) analyses using a General Time Reversible model with a gamma distribution: Percentage support ( $>50 \%$ ) from 1000 pseudoreplicates from ML and NJ analysis, respectively, are indicated next to supported node. The ' - ' indicates support value $<50 \%$. The tree is drawn to scale, with branch lengths in the same units as those of the evolutionary distances used to infer the phylogenetic tree. The analysis involved 70 nucleotide sequences and there were a total of 771 positions in the final dataset. The tree was rooted with the SSU sequence of Eimeria maxima [EF122251]. Sequences obtained in this study are identified by isolate number (e.g., 45901). The GenBank Accession number is in parenthesis. Isolates detected in this study are colour-coded. 


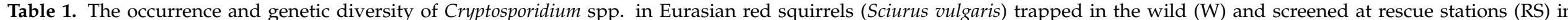

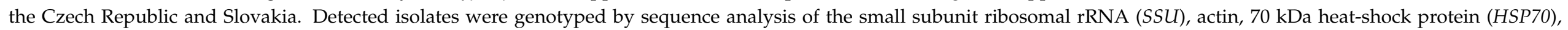

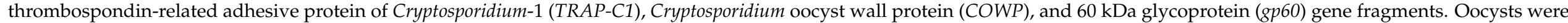
quantified by microscopy and were reported per gram of faeces (OPG).

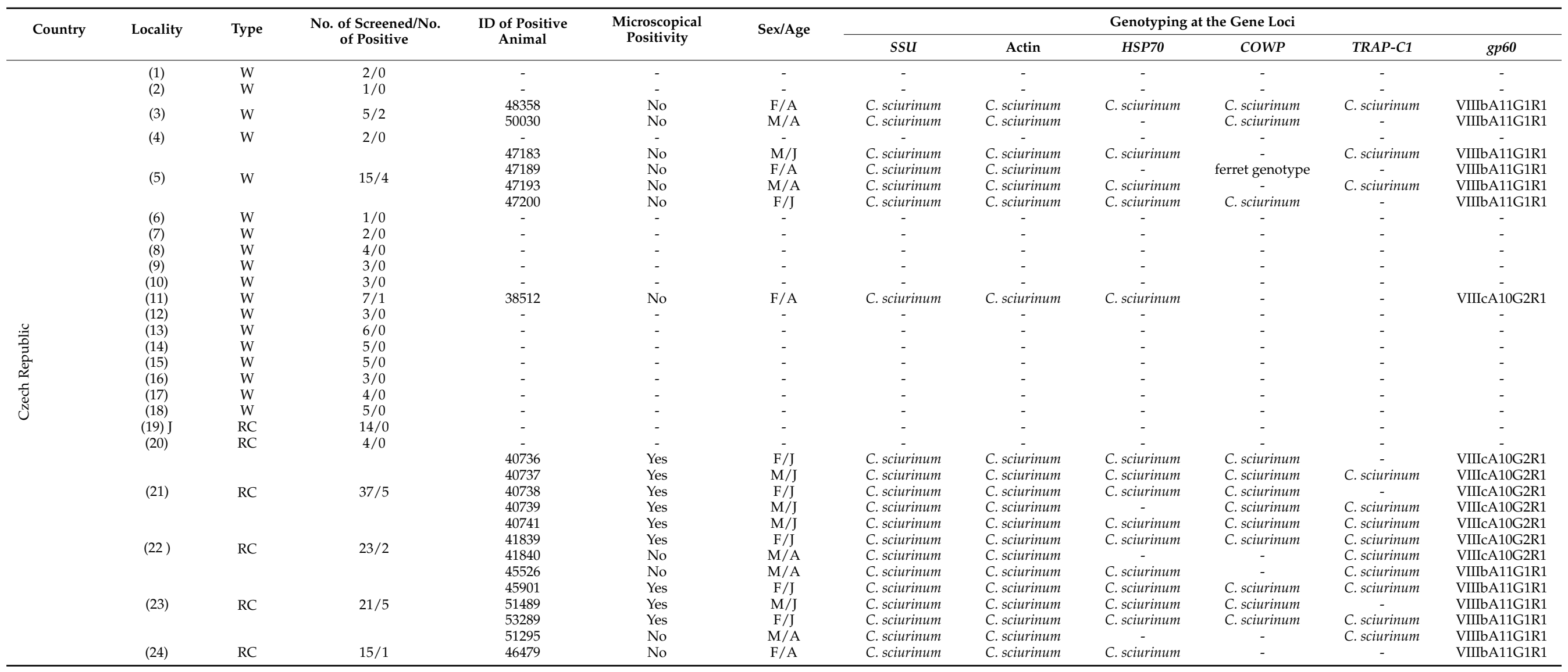


Table 1. Cont.

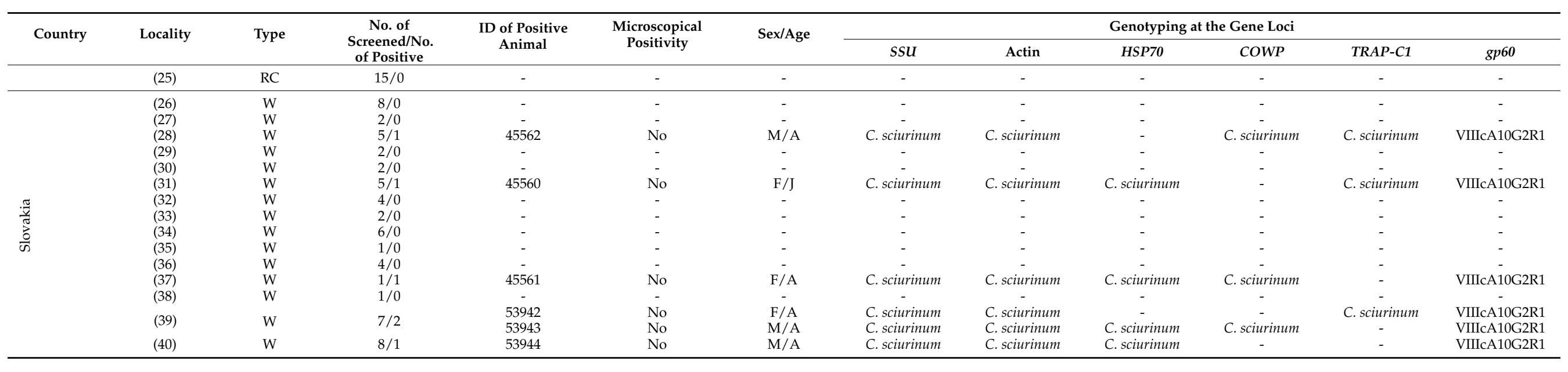




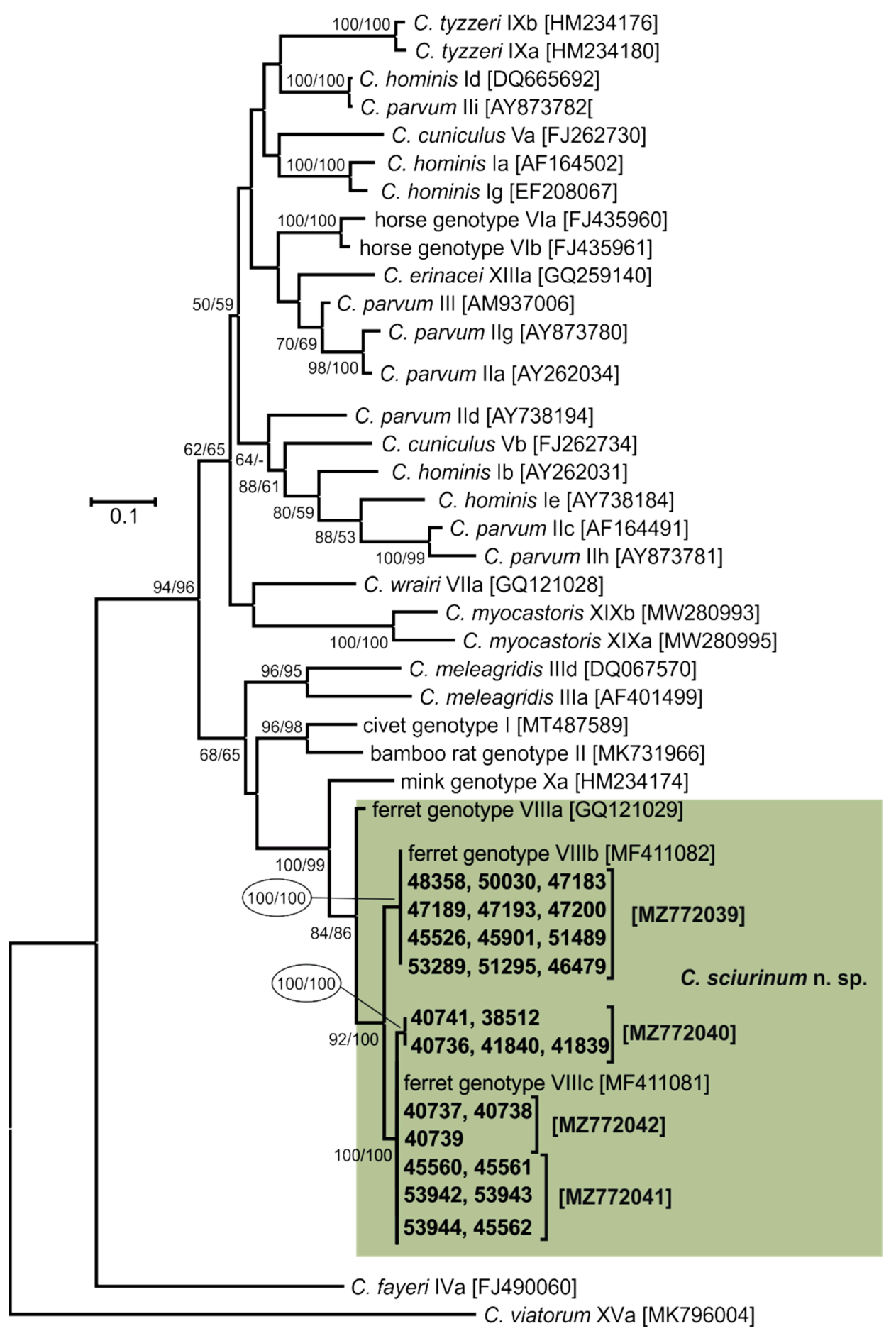

Figure 3. Evolutionary relationships of Cryptosporidium spp. at $60 \mathrm{kDa}$ glycoprotein (gp60) locus inferred by Maximum Likelihood (ML) and Neighbor-Joining (NJ) analyses using a General Time Reversible model with a gamma distribution: Percentage support ( $>50 \%$ ) from 1000 pseudoreplicates from ML and NJ analysis, respectively, are indicated next to supported node. The ' - ' indicates support value $<50 \%$. The tree is drawn to scale, with branch lengths in the same units as those of the evolutionary distances used to infer the phylogenetic tree. The analysis involved 58 nucleotide sequences and there were a total of 1134 positions in the final dataset. The tree was rooted with the gp60 sequence of Cryptosporidium viatorum [MK796004]. Sequences obtained in this study are identified by isolate number (e.g., 45901). The GenBank Accession number is in parenthesis. Isolates detected in this study are colour-coded. 
Microscopic, molecular, and histological examination of inoculated animals showed no evidence of infection in juvenile or adult SCID and BALB/c mice, Mongolian gerbils, guinea pigs, Southern multimammate mice, juvenile chickens, and adult budgerigars. For logistical reasons, we were unable to determine the infectivity of Cryptosporidium sp. ferret genotype for squirrels under experimental conditions. We therefore determined the infection intensity in squirrels of different ages kept at rescue stations. Nine of the eleven juvenile animals infected with Cryptosporidium sp. ferret genotype shed microscopically detectable oocysts $(18,000-74,000$ OPG). In contrast, oocyst numbers were below the detection limit (2000 OPG) in animals older than 10 weeks of age. The highest infection intensity was observed in animals aged 6-7 weeks (mean 49,666 OPG) compared to animals aged 4-5 weeks (mean 22,666 OPG) and 8-9 weeks (mean 21,000 OPG) (Figure 4). The consistency of the faeces and lack of faeces in the fur surrounding the rectum indicated an absence of diarrhoeal disease. Oocysts of Cryptosporidium sp. ferret genotype were spherical, with a thick, clear, and smooth oocyst wall. Oocysts from isolate 45901, which were measured in suspension after purification, measured $5.54 \times 5.22 \mu \mathrm{m}$, with a length to width ratio of 1.07 (Figure $5 \mathrm{a}$ ). There was no significant difference in oocyst size between isolate 45901 and other isolates (40793, 51489, and 53289; Table S2). Oocysts of Cryptosporidium sp. ferret genotype in the faecal smears stained by AVMC and ZN showed typical Cryptosporidium staining characteristics (Figure 5b,c) and cross-reacted with immunofluorescence reagents developed originally for C. parvum (Figure 5d,e). Oocysts that were dried and fixed onto slides for staining and labelling were smaller than those measured in suspension (data not shown).

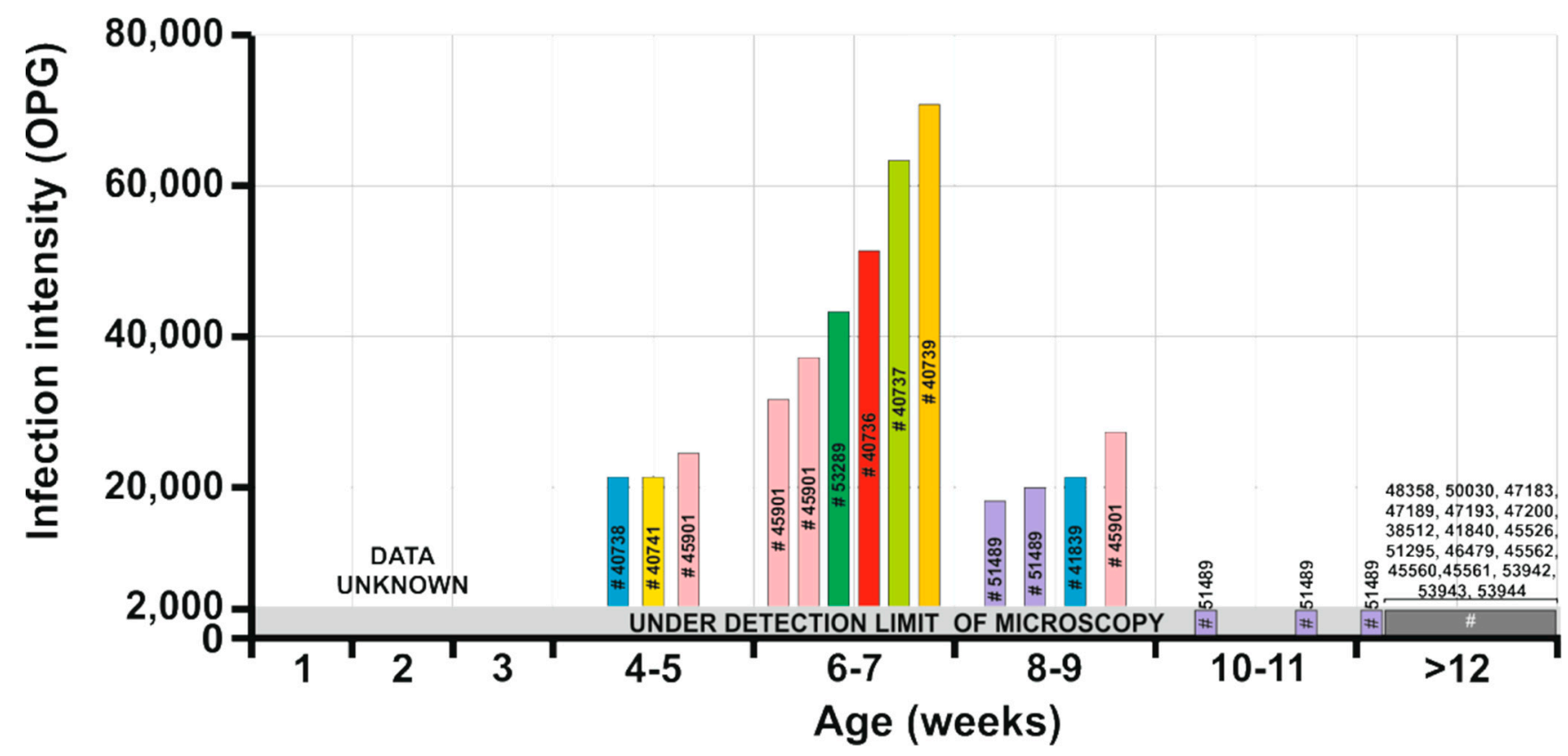

Figure 4. Infection intensity of Cryptosporidium sciurinum n. sp. in Eurasian red squirrels (Sciurus vulgaris) expressed as number of oocysts per gram of faeces (OPG). Data were collected from naturally infected Eurasian red squirrels. Animals aged 4-11 weeks old originated from rescue stations, and some of those animals were screened repeatedly (each animal is marked with a colour). The animal number (e.g., \#45901) corresponds with the numbers in Table 1. 


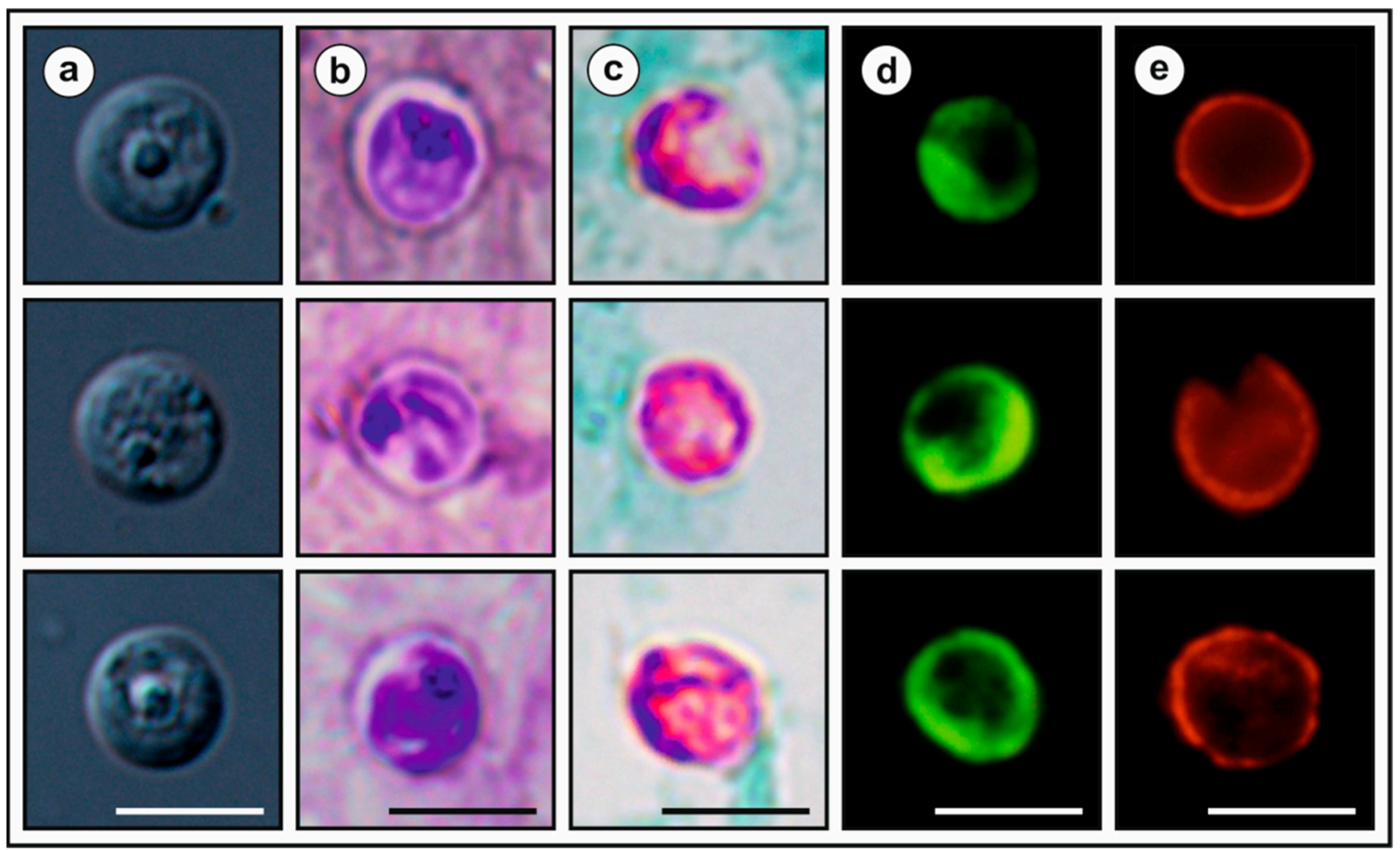

Figure 5. Oocysts of Cryptosporidium sciurinum n. sp. (a) under differential interference contrast microscopy, (b) stained by aniline-carbol-methyl violet staining, (c) stained by Ziehl-Nielsen staining, (d) labelled with anti-Cryptosporidium FITC-conjugated antibody, (e) labelled with anti-Cryptosporidium Cy3-conjugated antibody. Bar $=5 \mu \mathrm{m}$.

Based on the data presented here, we propose Cryptosporidium sp. ferret genotype as a new species-Cryptosporidium sciurinum n. sp.-, whose description is presented below.

\section{Taxonomic summary \\ Family Cryptosporidiidae Léger, 1911 \\ Genus Cryptosporidium Tyzzer, 1907 \\ Cryptosporidium sciurinum $\mathbf{n}$. sp.}

Syn: Cryptosporidium paroum ferret genotype ex black-footed ferret (Mustela nigripes) and Cryptosporidium sp. ferret genotype ex black-footed ferret (Mustela nigripes) of Xiao et al. [35].

Type-host: Sciurus vulgaris Linnaeus, 1758 (Rodentia: Muridae) Eurasian red squirrel. Other natural hosts: black-footed ferret (Mustela nigripes), Siberian chipmunk (Tamias sibiricus), Eastern chipmunk (Tamias striatus), budgerigar (Melopsittacus undulatus).

Type-locality: Třeboň, Czech Republic.

Other localities: České Budějovice, Brno, Praha, Vlašim, whole Czech Republic; Povážská Bystrica, Handlová, Gabčíkovo, Bratislava, Košice, whole Slovakia; Guangdong, China; Northern Italy; Georgia, USA.

Type-material: Faecal smear slides with oocysts stained by ACMV and ZN staining (nos. MV1-3/45901 and ZN1-2/45901) and gDNA isolated from faecal samples of a naturally infected Eurasian red squirrel (isolate 45901) are deposited at the Institute of Parasitology, Biology Centre of the Czech Academy of Sciences, Czech Republic.

Site of infection: unknown.

Distribution: As Cryptosporidium sp. ferret genotype ex Sciurus vulgaris: China, Italy [13,16,17]; as Cryptosporidium sp. ferret genotype or Cryptosporidium paroum ferret genotype ex Mustela nigripes: USA [35], as Cryptosporidium sp. ferret genotype ex Tamias striatus, T. sibiricus and Melopsittacus undulatus: China $[13,36]$.

Prepatent period: unknown. 
Patent period: At least 5 weeks in naturally infected Sciurus vulgaris (isolate 51489 in the present study).

Representative DNA sequences: Representative nucleotide sequences of SSU [MZ726453], actin [MZ772035], HSP70 [MZ772047], TRAP-C1 [MZ772037], COWP [MZ772045], and gp60 [MZ772039-MZ772042] genes are deposited in the GenBank database.

ZooBank registration: To comply with the regulations set out in Article 8.5 of the amended 2012 version of the International Code of Zoological Nomenclature (ICZN) [37], details of the new species have been submitted to ZooBank. The Life Science Identifier (LSID) of the article is urn:lsid:zoobank.org:pub:83ABAD68-07C6-4E51-8234- A2AC4C0EE72C. The LSID for the new name Cryptosporidium sciurinum n. sp. is urn:lsid:zoobank.org:act:E13F2B9FD9C6-4ED9-9EA8-B94AEB6189A2.

Etymology: The species name sciurinum is derived from the Latin noun sciurus, meaning squirrel.

Description. Oocysts of C. sciurinum n. sp. (isolate 45901) are spherical, measuring $5.12-6.00 \times 4.77-5.66(5.54 \pm 0.20 \times 5.22 \pm 0.18)$ with a length-to-width ratio of 1.00-1.26 $(1.07 \pm 0.05)$ (Figure 5). The oocyst wall is smooth and colourless (Figure 5a). The oocyst residuum is composed of numerous small granules and one spherical globule is clearly visible; a suture is not noticeable. Sporozoites are occasionally visible within oocysts. Morphology and morphometry of other developmental stages is unknown.

Remark 1. Oocysts of C. sciurinum n. sp. are stained by ACMV and ZN staining methods, similar to other Cryptosporidium spp. (Figure 5b,c), and their oocyst wall cross reacts with immunofluorescence reagents developed originally for C. parvum (Figure 5d,e). Oocysts from naturally infected squirrels did not differ significantly in size (Table S2). Oocysts of C. sciurinum n. sp. are larger than those of C. parvum $\left(\mathrm{T}^{2}=88.89, d f_{1}=2, d f_{2}=61.94\right.$, $p<0.001)$, C. occultus $\left(\mathrm{T}^{2}=45.84, d f_{1}=2, d f_{2}=65.83, p<0.001\right)$ and C. ratti $\left(\mathrm{T}^{2}=88.22\right.$, $\left.d f_{1}=2, d f_{2}=24.75, p<0.001\right)$, but these differences are not of practical significance for identification. Cryptosporidium sciurinum n. sp. can be differentiated genetically from other Cryptosporidium species based on sequences of SSU, actin, HSP70,TRAP-C1, COWP, and gp60 genes. At gp60 locus, C. sciurinum n. sp. is known to form three subtype families VIIIa, VIIIb, and VIIIc.

\section{Discussion}

Molecular studies conducted on three continents (North America, Europe, and Asia) have shown that tree squirrels host a variety of Cryptosporidium spp. [9-13,16,17]. While wild North American and Asian tree squirrels can be infected by a large number of species and genotypes of the genus Cryptosporidium [9-13], results from this and other studies suggest that wild Eurasian red squirrels are predominantly parasitized by C. sciurinum $\mathrm{n}$. sp. $[13,16,17]$. The only exceptions are two cases of Cryptosporidium sp. chipmunk genotype I, which naturally infects grey squirrels, and two cases of C. paroum reported in Eurasian red squirrels in Italy $[13,16,17]$. In contrast to wild animals, Eurasian red squirrels kept as caged pets in China were found to be infected with C. ratti and Cryptosporidium sp. chipmunk genotype III, which are specific for other hosts [13]. In the present study, $10.1 \%(26 / 258)$ of Eurasian red squirrels were infected with C. sciurinum n. sp. Previous studies of C. sciurinum n. sp. in Eurasian red squirrels have reported prevalences of $10.6 \%(13 / 123)$ and $21.5 \%$ $(15 / 70)$ in Italy and $26.3 \%$ in China $[13,16,17]$. The prevalence range of Cryptosporidium is similar with that found in other wild rodents, such as 14\% in Apodemus spp. in Europe, $27 \%$ in Apodemus speciosus in Japan, 16\% in brown rats (Rattus norvegicus) in Czech Republic, 12\% in muskrats (Ondatra zibethicus) in USA, 30\% in Chinese bamboo rats (Rhizomys sinensis) in China, or 7-14\% in voles in Europe [38-42]. Consistent with most reports describing natural infections with Cryptosporidium spp. in wild rodents [16,17,38,42-44], Eurasian red squirrels infected with C. sciurinum n. sp. shed low numbers of oocysts, often below the detection limit of microscopy. A characteristic of C. sciurinum n. sp. infection in Eurasian red squirrels is that mostly juveniles shed oocysts at levels that are detectable 
by microscopy $[16,17]$. This age-dependent variation in Cryptosporidium spp. infection intensity has been observed previously in several studies [44-49]. Juveniles are probably more susceptible to infection because of their naive and immature immune system, which permits a higher intensity of infection. The prepatent period of C. sciurinum $\mathrm{n}$. sp. is unknown. From the results we have collected, it is clear that pups become infected at a very early age (as early as 4 weeks), and that the infection persists for more than a month. It is possible that asymptomatically infected adults are a source of infection for their young, but this would need to be investigated experimentally. The pathogenicity of $C$. sciurinum n. sp. is unknown; however, based on the observations of naturally infected squirrels in rescue stations, this Cryptosporidium species appears to have low pathogenicity for infected individuals. This finding is consistent with previously published results [16,17].

Cryptosporidium sciurinum n. sp. was firstly identified in three naturally infected ferrets (reported as C. parvum ferret genotype (AF112572)) [35]. Since then, this species has been found in five captive chipmunks (T. sibiricus and T. striatus), one budgerigar (M. undulatus), and dozens of wild and captive Eurasian red squirrels $[13,15-17,35,36]$, suggesting that Eurasian red squirrels are a natural host of this parasite. This is supported by the finding in the present study that C. sciurinum n. sp. is not infective for SCID and BALB/c mice, Mongolian gerbils, guinea pigs, Southern multimammate mice, chickens, and budgerigars. The solitary infection reported in a budgerigar [36] could be the result of environmental contamination and the passage of oocysts or specific DNA through the digestive tract of a non-specific host, as has been described previously [50-53].

Oocysts of C. sciurinum n. sp. measured $5.54 \times 5.22 \mu \mathrm{m}$, which is similar in size to a previously published isolate of $C$. sciurinum $\mathrm{n}$. sp. $(5.5 \times 5.2 \mu \mathrm{m})$. Cryptosporidium sciurinum n. sp. is larger than C. parvum $(5.2 \times 4.9 \mu \mathrm{m})$ and C. ratti $(4.9 \times 4.6 \mu \mathrm{m})$, and is smaller than Cryptosporidium sp. chipmunk genotype I $(5.8 \times 5.4 \mu \mathrm{m})$, a species previously reported in Eurasian red squirrels $[16,40]$. However, the difference in size is not practically useful for distinguishing species by routine microscopy.

Although a description of oocyst morphology is a requirement for species description, molecular characterisation is necessary for species identification. Several previous studies have shown the presence of divergent copies of SSU gene within a Cryptosporidium species. Stenger et al. [54] found highly divergent SSU genotypes in Cryptosporidium sp. chipmunk genotype II. The co-occurrence of the genotypes in a host and the homogeneity of actin and $H S P 70$ sequences supported the conclusion that the divergent types are paralogs in a single Cryptosporidium lineage. Similarly, divergent types of SSU have been reported within, e.g., C. andersoni, C. apodemi, C. ditrichi, C. paroum, C. ubiquitum, Cryptosporidium sp. apodemus genotype I and II, or Cryptosporidium rat genotype II and III [15,42,43,55,56]. As inferring the evolutionary relationships of Cryptosporidium spp. using SSU sequences alone can lead to erroneous conclusions $[54,57,58]$, we included other polymorphic loci for our analyses. Although some previous studies have shown polymorphism in actin, HSP70, and TRAP-C1 genes in Cryptosporidium spp. [42,43,56], studies from our group and others have failed to find variants of these genes in C. sciurinum n. sp. [17,24,25]. All isolates of C. sciurinum n. sp. from the present study shared $100 \%$ identity at the COWP locus and differed from a sequence obtained from ferret (Mustela putorius furo) in Japan (AB469366) by a synonymous SNP $(\mathrm{C} / \mathrm{T})$ at position 387 . A similar synonymous SNP at the COWP locus was observed in geographically distinct isolates of C. tyzzeri [59].

Phylogenetic analyses of C. sciurinum n. sp. at SSU, actin, HSP70, TRAP-C1, COWP, and gp60 loci confirmed its status as a separate species from valid Cryptosporidium species. At all loci, C. sciurinum n. sp. formed a separate clade within the group of intestinal Cryptosporidium spp. that includes C. meleagridis, C. paroum, C. hominis, C. wrairi, and C. tyzzeri. At actin, HSP70, TRAP-C1, and COWP loci, the pairwise distances between $C$. sciurinum n. sp. and C. meleagridis (0.026, 0.036, 0.050, and 0.024 , respectively) are similar to those between $C$. andersoni and C. muris $(0.037,0.018,0.041$, and 0.018 , respectively) and $C$. hominis and C. paroum $(0.018,0.013,0.018$, and 0.016 , respectively). 
At the gp60 locus, only subtype families VIIIb and VIIIc were detected in the present study. Both subtypes have been found exclusively in Europe. In contrast, subtype VIIIa was found exclusively in China [13]. Other studies have found that $g p 60$ subtype families differ in their geographic distribution. For example, C. tyzzeri subtype IXa has been detected only in house mice (Mus musculus musculus) inhabiting Eastern Europe, China, and Kuwait, while subtype IXb is found (Mus musculus domesticus) in Western Europe, USA, and New Zealand [59]. A similar difference in distribution has been reported for C. parvum and C. ubiquitum gp60 subtypes [57,60]. It should be noted that gp60 subtype family VIIId was incorrectly reported in Eurasian red squirrels in Italy (the sequences actually belonged to C. parvum subtype IIa) and it should no longer be used for C. sciurinum n. sp. [17].

\section{Conclusions}

In summary, the present study confirms that Cryptosporidium sp. ferret genotype is genetically distinct from all currently accepted species of the genus Cryptosporidium, and its specificity for tree squirrels under natural conditions supports its description as a new species, which we propose be named Cryptosporidium sciurinum n. sp.

Supplementary Materials: The following are available online at https: / www.mdpi.com/article/ 10.3390/microorganisms9102050/s1: Figure S1. Evolutionary relationships of Cryptosporidium spp. at the actin locus inferred by Maximum Likelihood (ML) and Neighbor-Joining (NJ) analyses using the Tamura-3-parameter model with a gamma distribution: Percentage support $(>50 \%)$ from 1000 pseudoreplicates from ML and NJ analysis, respectively, are indicated next to supported node. The '-' indicates support value $<50 \%$. The tree is drawn to scale, with branch length in the same units as those of the evolutionary distances used to infer the phylogenetic tree. The analysis involved 69 nucleotide sequences and there were a total of 727 positions in the final dataset. The tree was rooted with the actin sequence of Plasmodium sp. [KF159609]. Sequences obtained in this study are identified by isolate number (e.g., 45901). The GenBank Accession number is in parenthesis. Isolates detected in this study are colour-coded. Figure S2. Evolutionary relationships of Cryptosporidium spp. at $70 \mathrm{kDa}$ heat-shock protein (HSP70) locus inferred by Maximum Likelihood (ML) and Neighbor-Joining (NJ) analyses using a General Time Reversible model with a gamma distribution: Percentage support (>50\%) from 1000 pseudoreplicates from ML and NJ analysis, respectively, are indicated next to supported node. The '-' indicates support value $<50 \%$. The tree is drawn to scale, with branch lengths in the same units as those of the evolutionary distances used to infer the phylogenetic tree. The analysis involved 69 nucleotide sequences and there were a total of 1728 positions in the final dataset. The tree was rooted with the HSP70 sequence of Eimeria maxima [Z46964]. Sequences obtained in this study are identified by isolate number (e.g., 45901). The GenBank Accession number is in parenthesis. Isolates detected in this study are colour-coded. Figure S3. Evolutionary relationships of Cryptosporidium spp. at thrombospondin-related adhesive protein of Cryptosporidium-1 (TRAP-C1) locus inferred by Maximum Likelihood (ML) and NeighborJoining (NJ) analyses using a General Time Reversible model with a gamma distribution: Percentage support (>50\%) from 1000 pseudoreplicates from ML and NJ analysis, respectively, are indicated next to supported node. The '-' indicates support value $<50 \%$. The tree is drawn to scale, with branch lengths in the same units as those of the evolutionary distances used to infer the phylogenetic tree. The analysis involved 29 nucleotide sequences and there were a total of 470 positions in the final dataset. The tree was rooted with the TRAP-C1 sequence of gastric Cryptosporidium spp. Sequences obtained in this study are identified by isolate number (e.g., 45901). The GenBank Accession number is in parenthesis. Isolates detected in this study are colour-coded. Figure S4. Evolutionary relationships of Cryptosporidium spp. at Cryptosporidium oocyst wall protein (COWP) locus inferred by Maximum Likelihood (ML) and Neighbor-Joining (NJ) analyses using a General Time Reversible model with a gamma distribution: Percentage support (>50\%) from 1000 pseudoreplicates from ML and NJ analysis, respectively, are indicated next to supported node. The '-' indicates support value $<50 \%$. The tree is drawn to scale, with branch lengths in the same units as those of the evolutionary distances used to infer the phylogenetic tree. The analysis involved 41 nucleotide sequences and there were a total of 477 positions in the final dataset. The tree was rooted with the COWP sequence of gastric Cryptosporidium spp. Sequences obtained in this study are identified by isolate number (e.g., 45901). The GenBank Accession number is in parenthesis. Isolates detected in this study are 
colour-coded. Table S1. Occurrence of Cryptosporidium sciurinum n. sp. in faeces of Eurasian red squirrels (Sciurus vulgaris) based on microscopic and molecular examination. Table S2. Size of Cryptosporidium sciurinum n. sp. oocysts obtained from naturally infected Eurasian red squirrels (Sciurus vulgaris).

Author Contributions: Conceptualization, M.K., J.J. and J.P.; methodology, D.R. and B.S.; software, M.R.; validation, J.P., J.J., M.K. and B.S.; formal analysis, J.P., J.J., N.H., R.K. and B.S.; investigation, J.J., J.P., N.H., B.S., D.R. and R.K.; resources, D.R., J.J., J.P., N.H. and B.S.; data curation, J.P., J.J., J.M. and M.R.; writing—original draft preparation, J.P. and J.J.; writing—review and editing, M.K. and J.M.; visualization, B.S. and M.K.; supervision, M.K. and J.M.; project administration, M.K.; funding acquisition, M.K. All authors have read and agreed to the published version of the manuscript.

Funding: This work was funded by GACR 21-23773S, and the Grant Agency of the University of South Bohemia (028/2019/Z).

Institutional Review Board Statement: The study was conducted according to the guidelines of the Declaration of Helsinki, and approved by the Institutional Ethics Committee of the Biology Centre of CAS (MZP/2019/603/1411 approved 10 June 2019, and 35/2018 1 May 2018).

Informed Consent Statement: Not applicable.

Data Availability Statement: Data is contained within the article or supplementary material.

Acknowledgments: We acknowledge the Laboratory of Electron Microscopy, Institute of Parasitology, Biology Centre, CAS supported by the MEYS CR (LM2015062 Czech-Bioimiging) for the preparation of specimens for electron microscopy.

Conflicts of Interest: None of the authors has any competing interest in the manuscript.

\section{References}

1. Nader, J.L.; Mathers, T.C.; Ward, B.J.; Pachebat, J.A.; Swain, M.T.; Robinson, G.; Chalmers, R.M.; Hunter, P.R.; van Oosterhout, C.; Tyler, K.M. Evolutionary genomics of anthroponosis in Cryptosporidium. Nat. Microbiol. 2019, 4, 826-836. [CrossRef]

2. Caccio, S.M.; Putignani, L. Epidemiology of Human Cryptosporidiosis. In Cryptosporidium: Parasite and Disease, 1st ed.; Cacciò, S.M., Widmer, G., Eds.; Springer: Vienna, Austria, 2014; pp. 43-80.

3. Kváč, M.; McEvoy, J.; Stenger, B.; Clark, M. Cryptosporidiosis in other vertebrates. In Cryptosporidium: Parasite and Disease, 1st ed.; Cacciò, S.M., Widmer, G., Eds.; Springer: Vienna, Austria, 2014; pp. 237-326.

4. Zahedi, A.; Bolland, S.J.; Oskam, C.L.; Ryan, U. Cryptosporidium abrahamseni n. sp. (Apicomplexa: Cryptosporidiiae) from red-eye tetra (Moenkhausia sanctaefilomenae). Exp. Parasitol. 2021, 223, 108089. [CrossRef]

5. Ryan, U.M.; Monis, P.; Enemark, H.L.; Sulaiman, I.; Samarasinghe, B.; Read, C.; Buddle, R.; Robertson, I.; Zhou, L.; Thompson, R.C.A.; et al. Cryptosporidium suis n. sp. (Apicomplexa: Cryptosporidiidae) in pigs (Sus scrofa). J. Parasitol. 2004, 90, 769-773. [CrossRef] [PubMed]

6. Bujila, I.; Troell, K.; Fischerstrom, K.; Nordahl, M.; Killander, G.; Hansen, A.; Soderlund, R.; Lebbad, M.; Beser, J. Cryptosporidium chipmunk genotype I-An emerging cause of human cryptosporidiosis in Sweden. Infect. Genet. Evol. 2021, 92, 104895. [CrossRef] [PubMed]

7. Sundberg, J.P.; Hill, D.; Ryan, M.J. Cryptosporidiosis in a gray squirrel. J. Am. Vet. Med. Assoc. 1982, 181, 1420-1422.

8. Current, W.L. Cryptosporidium spp. In Parasitic Infections in the Compromised Host; Walzer, P.D., Genta, R.M., Eds.; Dekker: New York, NY, USA, 1990; pp. 281-341.

9. Stenger, B.L.; Clark, M.E.; Kváč, M.; Khan, E.; Giddings, C.W.; Prediger, J.; McEvoy, J.M. North American tree squirrels and ground squirrels with overlapping ranges host different Cryptosporidium species and genotypes. Infect. Genet. Evol. 2015, 36, 287-293. [CrossRef]

10. Ziegler, P.E.; Wade, S.E.; Schaaf, S.L.; Chang, Y.F.; Mohammed, H.O. Cryptosporidium spp. from small mammals in the New York City watershed. J. Wildl. Dis. 2007, 43, 586-596. [CrossRef] [PubMed]

11. Ziegler, P.E.; Wade, S.E.; Schaaf, S.L.; Stern, D.A.; Nadareski, C.A.; Mohammed, H.O. Prevalence of Cryptosporidium species in wildlife populations within a watershed landscape in southeastern New York State. Vet. Parasitol. 2007, 147, 176-184. [CrossRef]

12. Feng, Y.; Alderisio, K.A.; Yang, W.; Blancero, L.A.; Kuhne, W.G.; Nadareski, C.A.; Reid, M.; Xiao, L. Cryptosporidium genotypes in wildlife from a New York watershed. Appl. Environ. Microbiol. 2007, 73, 6475-6483. [CrossRef] [PubMed]

13. Lv, C.; Zhang, L.; Wang, R.; Jian, F.; Zhang, S.; Ning, C.; Wang, H.; Feng, C.; Wang, X.; Ren, X.; et al. Cryptosporidium spp. in wild, laboratory, and pet rodents in china: Prevalence and molecular characterization. Appl. Environ. Microbiol. 2009, 75, 7692-7699. [CrossRef]

14. Chai, Y.J.; Deng, L.; Liu, H.F.; Yao, J.X.; Zhong, Z.J.; Xiang, L.Q.; Fu, H.L.; Shen, L.H.; Zhou, Z.Y.; Deng, J.L.; et al. First detection of Cryptosporidium spp. in red-bellied tree squirrels (Callosciurus erythraeus) in China. Parasite 2019, 26, 28. [CrossRef] [PubMed] 
15. Deng, L.; Chai, Y.; Luo, R.; Yang, L.; Yao, J.; Zhong, Z.; Wang, W.; Xiang, L.; Fu, H.; Liu, H.; et al. Occurrence and genetic characteristics of Cryptosporidium spp. and Enterocytozoon bieneusi in pet red squirrels (Sciurus vulgaris) in China. Sci. Rep. 2020, 10, 1026. [CrossRef] [PubMed]

16. Kváč, M.; Hofmannová, L.; Bertolino, S.; Wauters, L.; Tosi, G.; Modrý, D. Natural infection with two genotypes of Cryptosporidium in red squirrels (Sciurus vulgaris) in Italy. Folia Parasitol. 2008, 55, 95-99. [CrossRef]

17. Prediger, J.; Horčičková, M.; Hofmannová, L.; Sak, B.; Ferrari, N.; Mazzamuto, M.V.; Romeo, C.; Wauters, L.A.; McEvoy, J.; Kváč, M. Native and introduced squirrels in Italy host different Cryptosporidium spp. Eur. J. Protistol. 2017, 61, 64-75. [CrossRef] [PubMed]

18. Wauters, L.; Dhondt, A.A. Body-Weight, Longevity and Reproductive Success in Red Squirrels (Sciurus vulgaris). J. Anim. Ecol. 1989, 58, 637-651. [CrossRef]

19. Miláček, P.; Vítovec, J. Differential staining of cryptosporidia by aniline-carbol-methyl violet and tartrazine in smears from feces and scrapings of intestinal mucosa. Folia Parasitol. 1985, 32, 50.

20. Kváč, M.; Ondráčková, Z.; Květoňová, D.; Sak, B.; Vítovec, J. Infectivity and pathogenicity of Cryptosporidium andersoni to a novel host, southern multimammate mouse (Mastomys coucha). Vet. Parasitol. 2007, 143, 229-233. [CrossRef]

21. Arrowood, M.J.; Donaldson, K. Improved purification methods for calf-derived Cryptosporidium parvum oocysts using discontinuous sucrose and cesium chloride gradients. J. Eukaryot. Microbiol. 1996, 43, 89S. [CrossRef]

22. Sauch, J.F.; Flanigan, D.; Galvin, M.L.; Berman, D.; Jakubowski, W. Propidium iodide as an indicator of Giardia cyst viability. Appl. Environ. Microbiol. 1991, 57, 3243-3247. [CrossRef] [PubMed]

23. Xiao, L.; Escalante, L.; Yang, C.; Sulaiman, I.; Escalante, A.A.; Montali, R.J.; Fayer, R.; Lal, A.A. Phylogenetic analysis of Cryptosporidium parasites based on the small-subunit rRNA gene locus. Appl. Environ. Microbiol. 1999, 65, 1578-1583. [CrossRef]

24. Sulaiman, I.M.; Morgan, U.M.; Thompson, R.C.; Lal, A.A.; Xiao, L. Phylogenetic relationships of Cryptosporidium parasites based on the 70-kilodalton heat shock protein (HSP70) gene. Appl. Environ. Microbiol. 2000, 66, 2385-2391. [CrossRef]

25. Sulaiman, I.M.; Lal, A.A.; Xiao, L.H. Molecular phylogeny and evolutionary relationships of Cryptosporidium parasites at the actin locus. J. Parasitol. 2002, 88, 388-394. [CrossRef]

26. Spano, F.; Putignani, L.; Naitza, S.; Puri, C.; Wright, S.; Crisanti, A. Molecular cloning and expression analysis of a Cryptosporidium parvum gene encoding a new member of the thrombospondin family. Mol. Biochem. Parasitol. 1998, 92, 147-162. [CrossRef]

27. Jiang, J.; Alderisio, K.A.; Xiao, L. Distribution of Cryptosporidium genotypes in storm event water samples from three watersheds in New York. Appl. Environ. Microbiol. 2005, 71, 4446-4454. [CrossRef]

28. Spano, F.; Puri, C.; Ranucci, L.; Putignani, L.; Crisanti, A. Cloning of the entire COWP gene of Cryptosporidium parvum and ultrastructural localization of the protein during sexual parasite development. Parasitology 1997, 114 Pt 5, 427-437. [CrossRef] [PubMed]

29. Alves, M.; Xiao, L.H.; Sulaiman, I.; Lal, A.A.; Matos, O.; Antunes, F. Subgenotype analysis of Cryptosporidium isolates from humans, cattle, and zoo ruminants in Portugal. J. Clin. Microbiol. 2003, 41, 2744-2747. [CrossRef] [PubMed]

30. Hall, T.A. BioEdit: A user-friendly biological sequence alignment editor and analysis program for Windows 95/98/NT. Nucleic Acids. Symp. Ser. 1999, 41, 95-98.

31. Henriksen, S.A.; Pohlenz, J.F. Staining of cryptosporidia by a modified Ziehl-Neelsen technique. Acta Vet. Scand. 1981, 22, 594-596. [CrossRef] [PubMed]

32. Kváč, M.; Vítovec, J. Prevalence and pathogenicity of Cryptosporidium andersoni in one herd of beef cattle. J. Vet. Med. B 2003, 50, 451-457. [CrossRef]

33. Holubová, N.; Zikmundová, V.; Limpouchová, Z.; Sak, B.; Konečný, R.; Hlásková, L.; Rajský, D.; Kopacz, Z.; McEvoy, J.; Kváč, M. Cryptosporidium proventriculi sp. n. (Apicomplexa: Cryptosporidiidae) in Psittaciformes birds. Eur. J. Protistol. 2019, 69, 70-87. [CrossRef]

34. Team, R.C. R: A Language and Environment for Statistical Computing; R Foundation for Statistical Computing: Vienna, Austria, 2019.

35. Xiao, L.; Morgan, U.M.; Limor, J.; Escalante, A.; Arrowood, M.; Shulaw, W.; Thompson, R.C.; Fayer, R.; Lal, A.A. Genetic diversity within Cryptosporidium parvum and related Cryptosporidium species. Appl. Environ. Microbiol. 1999, 65, 3386-3391. [CrossRef]

36. Li, Q.; Li, L.; Tao, W.; Jiang, Y.; Wan, Q.; Lin, Y.; Li, W. Molecular investigation of Cryptosporidium in small caged pets in northeast China: Host specificity and zoonotic implications. Parasitol. Res. 2016, 115, 2905-2911. [CrossRef]

37. ICZN. International Commission on Zoological Nomenclature: Amendment of articles 8, 9, 10, 21 and 78 of the international code of zoologicalnomenclature to expand and refine methods of publication. Bull. Zool. Nomencl. 2012, 69, 161-169. [CrossRef]

38. Stenger, B.L.S.; Horčičková, M.; Clark, M.E.; Kváč, M.; Čondlová, S.; Khan, E.; Widmer, G.; Xiao, L.; Giddings, C.W.; Pennil, C.; et al. Cryptosporidium infecting wild cricetid rodents from the subfamilies Arvicolinae and Neotominae. Parasitology 2017, 145, 326-334. [CrossRef]

39. Li, F.L.; Zhang, Z.J.; Hu, S.H.; Zhao, W.T.; Zhao, J.G.; Kváč, M.; Guo, Y.Q.; Li, N.; Feng, Y.Y.; Xiao, L.H. Common occurrence of divergent Cryptosporidium species and Cryptosporidium parvum subtypes in farmed bamboo rats (Rhizomys sinensis). Parasites Vectors 2020, 13, 149. [CrossRef]

40. Ježková, J.; Prediger, J.; Holubová, N.; Sak, B.; Konečný, R.; Feng, Y.; Xiao, L.; Rost, M.; McEvoy, J.; Kváč, M. Cryptosporidium ratti n. sp. (Apicomplexa: Cryptosporidiidae) and genetic diversity of Cryptosporidium spp. in brown rats (Rattus norvegicus) in the Czech Republic. Parasitology 2021, 148, 84-97. [CrossRef] 
41. Murakoshi, F.; Fukuda, Y.; Matsubara, R.; Kato, Y.; Sato, R.; Sasaki, T.; Tada, C.; Nakai, Y. Detection and genotyping of Cryptosporidium spp. in large Japanese field mice, Apodemus speciosus. Vet. Parasitol. 2013, 196, 184-188. [CrossRef]

42. Čondlová, S.; Horčičková, M.; Havrdová, N.; Sak, B.; Hlásková, L.; Perec-Matysiak, A.; Kicia, M.; McEvoy, J.; Kváč, M. Diversity of Cryptosporidium spp. in Apodemus spp. in Europe. Eur. J. Protistol. 2019, 69, 1-13. [CrossRef]

43. Čondlová, S.; Horčičková, M.; Sak, B.; Květoňová, D.; Hlásková, L.; Konečný, R.; Stanko, M.; McEvoy, J.; Kváč, M. Cryptosporidium apodemi sp. n. and Cryptosporidium ditrichi sp. n. (Apicomplexa: Cryptosporidiidae) in Apodemus spp. Eur. J. Protistol. 2018, 63, 1-12. [CrossRef]

44. Horčičková, M.; Čondlová, S.; Holubová, N.; Sak, B.; Květoňová, D.; Hlásková, L.; Konečný, R.; Sedláček, F.; Clark, M.; Giddings, C.; et al. Diversity of Cryptosporidium in common voles and description of Cryptosporidium alticolis sp. n. and Cryptosporidium microti sp. n. (Apicomplexa: Cryptosporidiidae). Parasitology 2019, 146, 220-233. [CrossRef]

45. Holubová, N.; Sak, B.; Hlásková, L.; Květoňová, D.; Hanzal, V.; Rajský, D.; Rost, M.; McEvoy, J.; Kváč, M. Host specificity and age-dependent resistance to Cryptosporidium avium infection in chickens, ducks and pheasants. Exp. Parasitol. 2018, 191, 62-65. [CrossRef]

46. Pavlásek, I. Findings of cryptosporidia in the stomach of hens and of exotic and wild birds. Veterinářství (Czech) 2001, 51, 103-108.

47. Sreter, T.; Varga, I.; Bekesi, L. Age-dependent resistance to Cryptosporidium baileyi infection in chickens. J. Parasitol. 1995, 81, 827-829. [CrossRef]

48. Rhee, J.K.; So, W.S.; Kim, H.C. Age-dependent resistance to Cryptosporidium muris (strain MCR) infection in golden hamsters and mice. Korean J. Parasitol. 1999, 37, 33-37. [CrossRef]

49. Kváč, M.; Sak, B.; Květoňová, D.; Secor, W.E. Infectivity of gastric and intestinal Cryptosporidium species in immunocompetent Mongolian gerbils (Meriones unguiculatus). Vet. Parasitol. 2009, 163, 33-38. [CrossRef]

50. Kváč, M.; Kestřánová, M.; Květoňová, D.; Kotková, M.; Ortega, Y.; McEvoy, J.; Sak, B. Cryptosporidium tyzzeri and Cryptosporidium muris originated from wild West-European house mice (Mus musculus domesticus) and East-European house mice (Mus musculus musculus) are non-infectious for pigs. Exp. Parasitol. 2012, 131, 107-110. [CrossRef]

51. Graczyk, T.K.; Cranfield, M.R. Experimental transmission of Cryptosporidium oocyst isolates from mammals, birds and reptiles to captive snakes. Vet. Res. 1998, 29, 187-195.

52. Graczyk, T.K.; Cranfield, M.R.; Fayer, R. Oocysts of Cryptosporidium from snakes are not infectious to ducklings but retain viability after intestinal passage through a refractory host. Vet. Parasitol. 1998, 77, 33-40. [CrossRef]

53. Crawshaw, G.J.; Mehren, K.G. Cryptosporidiosis in Zoo and Wild Animals. In Erkrankungen der Zootiere, Verhandlungsbericht des 29, Proceedings of the Internationalen Symposiums Uber die Erkrankungen der Zootiere, Cardiff, UK, 20-24 May 1987; Internationales Symposium uber die Erkrankungen der Zoo- und Wildtiere: Berlin, Germany, 1987; pp. 353-362.

54. Stenger, B.L.; Clark, M.E.; Kváč, M.; Khan, E.; Giddings, C.W.; Dyer, N.W.; Schultz, J.L.; McEvoy, J.M. Highly divergent 18S rRNA gene paralogs in a Cryptosporidium genotype from eastern chipmunks (Tamias striatus). Infect. Genet. Evol. 2015, 32, 113-123. [CrossRef]

55. Le Blancq, S.M.; Khramtsov, N.V.; Zamani, F.; Upton, S.J.; Wu, T.W. Ribosomal RNA gene organization in Cryptosporidium parvum. Mol. Biochem. Parasitol. 1997, 90, 463-478. [CrossRef]

56. Ng-Hublin, J.S.; Singleton, G.R.; Ryan, U. Molecular characterization of Cryptosporidium spp. from wild rats and mice from rural communities in the Philippines. Infect. Genet. Evol. 2013, 16, 5-12. [CrossRef]

57. Li, N.; Xiao, L.; Alderisio, K.; Elwin, K.; Cebelinski, E.; Chalmers, R.; Santin, M.; Fayer, R.; Kváč, M.; Ryan, U.; et al. Subtyping Cryptosporidium ubiquitum, a zoonotic pathogen emerging in humans. Emerg. Infect. Dis. 2014, 20, 217-224. [CrossRef] [PubMed]

58. Ježková, J.; Limpouchová, Z.; Prediger, J.; Holubová, N.; Sak, B.; Konečný, R.; Květoňová, D.; Hlásková, L.; Rost, M.; McEvoy, J.; et al. Cryptosporidium myocastoris n. sp. (Apicomplexa: Cryptosporidiidae), the Species Adapted to the Nutria (Myocastor coypus). Microorganisms 2021, 9, 813. [CrossRef] [PubMed]

59. Kváč, M.; McEvoy, J.; Loudová, M.; Stenger, B.; Sak, B.; Květoňová, D.; Ditrich, O.; Rašková, V.; Moriarty, E.; Rost, M.; et al. Coevolution of Cryptosporidium tyzzeri and the house mouse (Mus musculus). Int. J. Parasitol. 2013, 43, 805-817. [CrossRef] [PubMed]

60. Xiao, L. Molecular epidemiology of cryptosporidiosis: An update. Exp. Parasitol. 2010, 124, 80-89. [CrossRef] 